\title{
Some New Emerging Viral Diseases in South America and East Africa: The Four Viruses, Itaya, Iquitos, Ngari and Ilesha Virus
}

Somsri Wiwanitkit ${ }^{* 1}$ and Viroj Wiwanitkit ${ }^{2}$

${ }^{1}$ Wiwanitkit House, Bangkhae, Bangkok Thailand

${ }^{2}$ Hainan Medical University, China

\begin{abstract}
New emerging viral disease is usually a problematic scenario in public health. There are several new emerging viral diseases in the present day. Those diseases can be the possible cause of worldwide pandemic and the surveillance is needed. Here, the authors briefly summarize and discuss on some new emerging viral diseases in South America and East Africa (Itaya, Iquitos, Ngari and Ilesha viruses).
\end{abstract}

Keywords: Emerging; Virus; Itaya; Iquitos; Batai; Ngari; Ilesha Introduction

New emerging viral disease is usually a problematic scenario in public health. There are several new emerging viral diseases in the present day. In fact, thousand kinds of viruses exist in our world and many are pathogenic [1,2]. Some pathogenic viruses cause severe diseases but it has been known for few years. With advent in laboratory medicine technique, there are several newly discovered and identified new pathogenic viruses $[1,2]$. Those newly identified viruses usually cause new illnesses that are hard- to-diagnose and treat. Those diseases can be the possible cause of worldwide pandemic and the surveillance is needed. Here, the authors briefly summarize and discuss on some new emerging viral diseases in South America and East Africa (Itaya, Iquitos, Ngari and Ilesha viruses).

\section{Itaya virus}

Itaya virus is a new virus that has just been mentioned for a few years. It was firstly isolated in 1999 and 2006 from febrile patients in Peru [3]. Its first genetic composition finding is by a research team in Peru. Hontz et al. found that this virus was a bunyavirus with identified genetic reassortment [3]. There are extremely limited knowledge on this new virus, hence, further studies on this virus is suggested. Of interest, this new virus was firstly detected in Iquito, which is the endemic area of another new virus Iquitos virus [4], which will be further mentioned in this short article.

\section{Iquitos virus}

Iquitos virus is another new virus that has just been mentioned for a few years. It is also in the group of bunyavirus. This virus is also firstly reported from Peru. The genetic reassortment of this virus contains "the $S$ and $L$ segments of Oropouche virus and the $M$ segment of a novel Simbu serogroup virus [4]". It is the cause of outbreaks of "Oropouche fever" during 2005 and 2006 in Peru. High seroprevelance positive rate can be seen in Peru [4]. Aguilar et al. mentioned for "the need for strengthening surveillance activities and laboratory capabilities, and investigating the emergence of new pathogens in tropical regions of South America [4]." Of interest, the site of epidemic of this virus, Iquitos, is also the endemic area of other tropical viral diseases, especially for dengue [5,6] and Venezuelan equine encephalitis [7]. It can be expected that the Iquitos has already been existed in this area for a very long time but it is not recognized and some infected cases might be misdiagnosed as other common viral diseases. Focusing on Oropouche virus which contributes to a new Iquitos virus, it has already existed and been endemic in Iquitos for a long time. The finding of high prevalence of Oropouche virus relating to the increasing population of biting midges are also reported in this area [8].

\section{Ngari virus}

Ngari virus is a new virus seen in East Africa. This virus is an orthobunyavirus with a reassortant between Bunyamwera virus and an $M$ segment donated from Batai virus [9-11]. Of interest, Batai virus, the starting donor virus of the new Ngari virus, can cause a mild febrile human illness [12]. However, when the reassorement occurs, the resulted virus is highly virulent [12]. Tracking for the viral origin, it is mentioned that the development of virus occurs in Sudan and Uganda. The first isolation in human is reported from Senegal [13]. Mosquito is believed to be the vector of this virus [13]. The Ngari virus can cause severe febrile illness [9] and can also cause hemorrhagic complication [14]. The virus can be seen in animals and it is believed that the animals can be the reservoir host [15]. In a recent report by Eiden et al. [15], there is a high rate of Ngari virus in goats during Rift Valley fever outbreak. Of interest, Ngari virus is reported for high structural similarity with another new emerging virus, Ilesha that is also detected in Africa [16].

\section{Ilesha virus}

Ilesha virus is another new virus firstly seen in Madagascar $[16,17]$. It is another arthropod borne virus. It belongs to the genus Orthobunyavirus of the Bunyaviridae family $[16,17]$. This virus can be seen in several African countries [16,17]. It can cause human illness characterized by febrile illness with erythema [16-18] (before the detection of virus, the illness is called Ilesha shake [18]. It also can present hemorrhagic complications and fatal meningoencephalitis $[16,17]$. Pachler et al. reported that "lesha virus segments S and L exhibit highest genetic conservation with Bunyamwera virus and Ngari virus [16]." Similar to Ngari virus, this virus can also be seen in animals and it is believed that the animals can be the reservoir host [19].

*Corresponding author: Somsri Wiwanitkit, Wiwanitkit House, Bangkhae, Bangkok, Thailand, Tel: +6624132436; E-mail: somsriwiwan@hotmail.com

Received May 12, 2015; Accepted May 25, 2015; Published June 01, 2015

Citation: Somsri W and Viroj W (2015) Some New Emerging Viral Diseases in South America and East Africa: The Four Viruses, Itaya, Iquitos, Ngari and Ilesha Virus. J Trop Dis 3: 160. doi: 10.4172/2329-891X.1000160

Copyright: () 2015 Somsri W, et al. This is an open-access article distributed under the terms of the Creative Commons Attribution License, which permits unrestricted use, distribution, and reproduction in any medium, provided the original author and source are credited. 
Citation: Somsri W and Viroj W (2015) Some New Emerging Viral Diseases in South America and East Africa: The Four Viruses, Itaya, Iquitos, Ngari and Ilesha Virus. J Trop Dis 3: 160. doi: 10.4172/2329-891X.1000160

\section{Other emerging viruses in non-tropical countries}

Apart from the mentioned viruses, there are also some new emerging viruses in non-tropical countries. Some of those viruses can attack human beings while the others cannot. For example, Schmallenberg virus is a new viruses firstly reported in 2011 [20-22]. This virus is a novel orthobunyavirus of the Simbu serogroup [20-22]. It can be seen in many European countries and mainly attack cattle [2022]. Severe fever thrombocytopenia syndrome virus is another new discovered virus in East Asia [19-20]. The mode of transmission is not clear but it can be transmitted by tick bite and person to person blood contact $[23,24]$. This virus can cause human infection with high fatality $[23,24]$.

\section{Conclusion}

The four mentioned viruses are the examples of the new viruses that cause new emerging viruses diseases. Itaya virus and Iquitos virus can be new problem in South America whereas Ngari virus might be the future problem in East Africa. It is necessary to have a good plan to correspond to these new emerging tropical virus infections. In addition to the mentioned three viruses that emerged in the tropical regions, there are also other new viruses emerging in non-tropical zones. For sure, the similar surveillance and control have to be applied for those new viruses.

\section{References}

1. Lipkin WI, Anthony SJ (2015) Virus hunting. Virology. 479-480C:194-199.

2. Voide C, Asner S, Giulieri S, Cavassini M, Merz L, et al. (2014) Infectious diseases. Rev Med Suisse. 15: 10(412-413):61-5.

3. Hontz RD, Guevara C, Halsey ES, Silvas J, Santiago FW, Widen SG, et al. (2015) Itaya virus, a Novel Orthobunyavirus Associated with Human Febrile Illness, Peru. Emerg Infect Dis. 21.

4. Aguilar PV, Barrett AD, Saeed MF, Watts DM, Russell K, Guevara C, et al. (2011) Iquitos virus: a novel reassortant Orthobunyavirus associated with human illness in Peru. PLoS Negl Trop Dis. 5: e1315.

5. Durand Velazco S, Fiestas Solórzano V, Sihuincha Maldonado M, Chávez Lencinas C, Vásquez Vela V, Torrejón Flores C (2011) Impact of the dengue epidemic due to a new lineage of DENV-2 American/ Asian genotype in the health services demand in hospital "Cesar Garayar Garcia", Iquitos. Rev Peru Med Exp Salud Publica. 28: 157-159.

6. Morrison AC, Minnick SL, Rocha C, Forshey BM, Stoddard ST, Getis A (2010) Epidemiology of dengue virus in Iquitos, Peru 1999 to 2005: interepidemic and epidemic patterns of transmission. PLoS Negl Trop Dis. 4: e670.

7. Morrison AC, Forshey BM, Notyce D, Astete H, Lopez V, Rocha C (2008) Venezuelan equine encephalitis virus in Iquitos, Peru: urban transmission of a sylvatic strain. PLoS Negl Trop Dis. 2: e349.

8. Mercer DR, Castillo-Pizango MJ (2005) Changes in relative species compositions of biting midges (Diptera: Ceratopogonidae) and an outbreak of Oropouche virus in lquitos, Peru. J Med Entomol. 42: 554-558.

9. Briese T, Bird B, Kapoor V, Nichol ST, Lipkin WI (2006) Batai and Ngari viruses: $M$ segment reassortment and association with severe febrile disease outbreaks in East Africa. J Virol. 80: 5627-5630.

10. Odhiambo C, Venter M, Limbaso K, Swanepoel R, Sang R (2014) Genome sequence analysis of in vitro and in vivo phenotypes of Bunyamwera and Ngari virus isolates from northern Kenya. PLoS One. 9: e105446.

11. Groseth A, Weisend C, Ebihara H (2012) Complete genome sequencing of mosquito and human isolates of Ngari virus. J Virol. 86: 13846-13847.

12. Lambert AJ, Huhtamo E, Di Fatta T, De Andrea M, Borella A, Vapalahti O (2014) Serological evidence of Batai virus infections, bovines, northern Italy, 2011. Vector Borne Zoonotic Dis. 14: 688-689.

13. Zeller HG, Diallo M, Angel G, Traoré-Lamizana M, Thonnon J, Digoutte JP, et al. (1996) Ngari virus (Bunyaviridae: Bunyavirus). First isolation from humans in Senegal, new mosquito vectors, its epidemiology. Bull Soc Pathol Exot. 89 12-16.

14. Gerrard SR, Li L, Barrett AD, Nichol ST (2004) Ngari virus is Bunyamwera virus reassortant that can be associated with large outbreaks of hemorrhagic fever in Africa. J Virol. 78: 8922-8926.

15. Eiden M, Vina-Rodriguez A, El Mamy BO, Isselmou K, Ziegler U, et al. (2014) Ngari virus in goats during Rift Valley fever outbreak, Mauritania, 2010. Emerg Infect Dis 20:2174-2176.

16. Pachler K, Růžek D, Nowotny N (2013) Molecular characterization of the African orthobunyavirus llesha virus. Infect Genet Evol 20:124-130.

17. Morvan JM, Digoutte JP, Marsan P, Roux JF (1994) Ilesha virus: a new aetiological agent of haemorrhagic fever in Madagascar. Trans R Soc Trop Med Hyg 88: 205.

18. Pearson CA, Moore DL, David-West TS (1973) Virus studies in "llesha shakes". West Afr Med J Niger Med Dent Pract 22: 20-22.

19. Fagbami AH, Fabiyi A (1975) A survey for llesha Bunyamwera group virus antibodies in sera from domestic animals and humans in three ecological zones of Nigeria. Virologie 26: 27.

20. Beer M, Conraths FJ, van der Poel WH (2013) 'Schmallenberg virus'-a nove orthobunyavirus emerging in Europe. Epidemiol Infect 141: 1-8.

21. Conraths FJ, Peters M, Beer M (2013) Schmallenberg virus, a nove orthobunyavirus infection in ruminants in Europe: potential global impact and preventive measures. N Z Vet J 61: 63-67.

22. Wernike K, Hoffmann B, Beer M (2013) Schmallenberg virus. Dev Biol (Basel) 135:175-182.

23. Li D (2015) Severe Fever with Thrombocytopenia Syndrome: A newly discovered emerging infectious disease. Clin Microbiol Infect pii: S1198$743 \times(15) 00322-5$

24. Yasukawa M (2015) Severe fever with thrombocytopenia syndrome, an emerging infectious disease for hematologists. Rinsho Ketsueki 56: 3-8. 